Published in final edited form as:

Biochem Biophys Res Commun. 1995 March 17; 208(2): 871-878.

\title{
PRESENCE OF BOTH $A_{1}$ AND $A_{2 a}$ ADENOSINE RECEPTORS IN HUMAN CELLS AND THEIR INTERACTION
}

\author{
Ahmed H. Ahmed ${ }^{1}$, Kenneth A. Jacobson ${ }^{2}$, Jeongho Kim², and Leon A. Heppel ${ }^{1}$ \\ ${ }^{1}$ Section of Biochemistry, Molecular and Cell Biology, Cornell University, Ithaca, NY 14853 \\ 2laboratory of Chemistry, N.I.D.D.K., N.I.H., Bethesda, MD 20892
}

\section{SUMMARY}

We have obtained pharmacological evidence for the expression of both $\mathrm{A}_{1^{-}}$(inhibitory) and $\mathrm{A}_{2 \mathrm{a}^{-}}$ (stimulatory) adenosine receptors in cultured human foreskin fibroblasts and lung fibroblasts. The $A_{1}$ receptors were sufficiently abundant in foreskin fibroblasts so that binding studies with a radioactively labeled specific ligand confirmed their existence. Both receptors were activated during the stimulation of cAMP accumulation and DNA synthesis by adenosine.

Adenosine activates specific cell surface receptors, which there upon regulate a variety of physiological functions. Adenosine receptors were originally classified by Burnstock [reviewed in (1)] as $\mathrm{P}_{1}$ to distinguish them from $\mathrm{P}_{2}$ receptors which interact mainly with ATP. Later, the $\mathrm{P}_{1}$-adenosine receptors were further subdivided into $\mathrm{A}_{1}$ and $\mathrm{A}_{2}$ receptors based on selectivity for a series of adenosine analogues $(2,3)$. Demonstration of adenosine receptors in many types of cells has been made primarily by functional assays. Thus, it was found that $\mathrm{A}_{2 \mathrm{a}}$-adenosine receptors stimulated adenylyl cyclase, while $\mathrm{A}_{1}$ receptors inhibited this enzyme (1). This occurs by way of coupling to $G_{i}$ (inhibitory) or $G_{s}$ (stimulatory), intermediary ATP-binding proteins. Today it is realized that $\mathrm{A}_{1}$-adenosine receptors also stimulate other functions such as the opening of $\mathrm{K}^{+}$channels (1).

There have been a few reports in which it was found that a single cell coexpresses both $\mathrm{A}_{1^{-}}$and $\mathrm{A}_{2 \mathrm{a}}$-adenosine receptors $(1,3,4)$. The best documented case concerns the $\mathrm{DDT}_{1}-\mathrm{MF} 2$ smooth muscle cell line (3). In the present investigation, we obtained pharmacological evidence for the expression of both $\mathrm{A}_{1}$ - and $\mathrm{A}_{2 \mathrm{a}}$-adenosine receptors in the FS4 cell line derived in 1973 from human foreskin tissue (5), in cultures of human foreskin fibroblasts isolated within the past year, and in IMR90 human lung fibroblasts (6). The data suggest that both $\mathrm{A}_{1}$ and $\mathrm{A}_{2 \mathrm{a}}$ receptors are activated during the stimulation of cAMP accumulation and DNA synthesis by adenosine in foreskin fibroblasts.

\section{MATERIALS AND METHODS}

\section{Materials}

Nucleotides, insulin and adenosine were from Boehringer Mannheim. Pertussis toxin was obtained from List Laboratories, Campbell, CA. Epidermal growth factor (EGF) was obtained from Upstate Biotechnology, Inc. $\left[{ }^{3} \mathrm{H}\right]$ Thymidine and cAMP assay kits were 
purchased from Amersham Corporation. Culture media and fetal bovine serum (FBS) were obtained from Life Technologies, Inc. Other reagents were purchased from Sigma.

\section{Cell culture}

FS4 cells were kindly supplied by Dr. J. Vilcek of New York University Medical Center. Human foreskin fibroblast cells were obtained from Advanced Biotechnologies, Inc., Columbia, MD. Human embryo lung fibroblasts (IMR90, 22-26 doublings) were from the Coriell Institute for Medical Research, Camden, NJ. Cells were grown in Dulbecco's modified Eagle's medium (DMEM) as described $(6,7)$.

\section{DNA synthesis}

Quiescent cultures were washed with a 1:1 mixture of DMEM and Waymouth's medium and incorporation of $\left[{ }^{3} \mathrm{H}\right]$ thymidine $(0.25 \mu \mathrm{Ci} / \mathrm{ml}, 1 \mu \mathrm{M})$ was performed as described (7). After a $40 \mathrm{~h}$ incubation at $37^{\circ} \mathrm{C}$, acid-insoluble radioactivity was measured. A 24-h incubation before addition of isotope ("serum starvation") was not necessary to reveal stimulation by ATP or adenosine, but this treatment made the cells more responsive to LPA.

\section{Measurement of cAMP accumulation}

Quiescent cultures were washed and incubated at $37^{\circ} \mathrm{C}$ for $2-3 \mathrm{~h}$ with a $1: 1$ mixture of DMEM and Waymouth's medium. RO20-1724 $(10 \mu \mathrm{M})$ was added 5 min before other required additions except for Fig. 2. After $15 \mathrm{~min}$, or as indicated, at $37^{\circ} \mathrm{C}$, intracellular cAMP accumulation was measured with a binding protein assay kit obtained from Amersham Corporation.

\section{Assay: Radioligand binding}

Membranes prepared as described (3) were tested in radioligand binding assays (8) for the presence of $\mathrm{A}_{1}$ and $\mathrm{A}_{2 \mathrm{a}}$ receptors, using $\left[{ }^{3} \mathrm{H}\right] \mathrm{CPX}$ and $\left[{ }^{3} \mathrm{H}\right] \mathrm{CGS} 21680$, respectively. Membranes were resuspended in $50 \mathrm{mM}$ Tris (pH 7.4), $10 \mathrm{mM} \mathrm{MgCl}_{2}, 0.01 \%$ CHAPS, and $100 \mu \mathrm{l}$ membrane solution was used for saturation binding to $\mathrm{A}_{1}$ receptors; the membrane concentration was $0.2 \mathrm{mg}$ protein per $\mathrm{ml}$. Appropriate $\left[{ }^{3} \mathrm{H}\right] \mathrm{CPX}(109 \mathrm{Ci} / \mathrm{mmol})$ was added and the mixture was incubated at $37^{\circ} \mathrm{C}$ for $1 \mathrm{~h}$. Two units $/ \mathrm{ml}$ adenosine deaminase were added. NECA (final, $400 \mu \mathrm{M}$ ) was used as a non-specific reagent. Binding was terminated by rapid filtration with the same ice-cold buffer, using a Brandel cell harvester and Whatman $\mathrm{GF} / \mathrm{B}$, glass fiber filters.

\section{RESULTS}

For all results, similar data were obtained with each of the three cell types. Thus, adenosine shares with ATP, ADP and AMPPNP the distinction of being an unusually effective mitogen when presented to FS4, HFF or IMR90 cells in the absence of other growth factors. The stimulation of $\left[{ }^{3} \mathrm{H}\right]$ thymidine incorporation was greater than seen for EGF or fetal bovine serum (Fig. 1). The unusually good mitogenic activity for these adenine derivatives was reported for another primate line, the African green monkey kidney epithelial cells (BSC-1) (9). Other evidence for mitogenic stimulation by adenosine included increases in percent 
nuclear labeling by $\left[{ }^{3} \mathrm{H}\right]$ thymidine, chemical assay for cellular DNA using the bisbenzamide reaction (13), and cell counts (data not shown).

LPA, a mitogen of great current interest (7), synergizes with adenosine or ATP. In HFF cells, incorporation with $\left[{ }^{3} \mathrm{H}\right]$ thymidine was stimulated 13.5 fold by $50 \mu \mathrm{M}$ adenosine, 3.7 fold by $20 \mu \mathrm{M}$ LPA, and 29 fold by combined adenosine and LPA. No other pairs of mitogens were as effective.

\section{Evidence for $\mathrm{A}_{2 \mathrm{a}}$-adenosine receptors}

We observed dose-dependent accumulation of cAMP when FS4 cells were incubated with adenosine (Fig. 2), or with the analogue, APEC, which is a highly specific agonist for $\mathrm{A}_{2 \mathrm{a}}$ receptors (Fig. 3). The specific antagonist for $\mathrm{A}_{2 \mathrm{a}}$ receptor binding, CSC, reduced intracellular cAMP levels that had been elevated by APEC (Fig. 4). CSC also reduced the accumulation of cAMP that had been stimulated by adenosine (Fig. 5). In addition, prolonged $(24 \mathrm{~h})$ preincubation of FS4 cells with APEC caused partial reduction of cAMP accumulation stimulated by adenosine, presumably due to selective desensitization of the $\mathrm{A}_{2 \mathrm{a}}$-adenosine receptor (Fig. 2). Further evidence for the presence of $\mathrm{A}_{2 \mathrm{a}}$-adenosine receptors in FS4, HFF and IMR90 cells is provided by the fact that pretreatment with cholera toxin (CTX) enhanced the elevation of cAMP levels produced by incubation with adenosine or APEC. In a typical experiment, similar to that described in Fig. 2, pmoles of cAMP per mg protein, formed in $15 \mathrm{~min}$, were: Basal, 14; CTX, $50 \mathrm{ng} / \mathrm{ml}, 200$; adenosine, $25 \mu \mathrm{M}, 50$; adenosine plus CTX, 1200.

\section{Presence of $A_{1}$-adenosine receptors expressed in FS4, HFF and IMR90 cells}

The presence of $A_{1}$ receptors in human cells was demonstrated by finding partial inhibition of cAMP accumulation caused by isoproterenol or forskolin, in the presence of the $A_{1}$ agonists R-PIA or CPA. The inhibition induced by R-PIA or CPA was overcome by having the specific $\mathrm{A}_{1}$ antagonist, $\mathrm{CPX}$, also present. For example, cAMP accumulation (pmoles/mg protein), in an experiment similar to Fig. 2, was as follows: Basal, 53; $0.1 \mu \mathrm{M}$ R-PIA, 48; $10 \mu \mathrm{M}$ isoproterenol, 695; isoproterenol plus R-PIA, 520; isoproterenol plus RPIA plus $50 \mathrm{nM}$ CPX, 660. In addition to the specific antagonist, CPX, pretreatment with pertussis toxin (which inactivates $G_{i a}$ ) also overcame the effect of R-PIA.

\section{Radioligand binding in FS4 and HFF cell membranes}

In saturation experiments with membranes from FS4 and HFF cells, there was considerable $\left[{ }^{3} \mathrm{H}\right] \mathrm{CPX}$ binding (for FS4, $\mathrm{n}=1 ; \mathrm{K}_{\mathrm{a}}=21 \mathrm{nM} ; \beta_{\max }=1.1$ pmole/mg protein). However, in both FS4 and HFF cell membranes, there was no detectable specific binding to $\mathrm{A}_{2 \mathrm{a}}$ receptors. Thus, the binding data provide additional evidence for $\mathrm{A}_{1}$-adenosine receptors only.

\section{Evidence for an interaction between the $A_{1}$ - and $A_{2 a}$-adenosine receptors during adenosine-stimulated $\left[{ }^{3} \mathrm{H}\right]$ thymidine incorporation}

Fig. 7 shows that prolonged ( $24 \mathrm{~h}$ ) preincubation of FS4 cells with the $\mathrm{A}_{1}$ agonists CPA and R-PIA, or $\mathrm{A}_{2 \mathrm{a}}$ agonist APEC, partially reduced the mitogenic response to adenosine. A partial reduction was also obtained after a brief $(1 \mathrm{~h})$ exposure of FS4 cells to $10 \mu \mathrm{M}$ NECA, 
conditions reported to cause complete desensitization of $\mathrm{A}_{2 \mathrm{a}}$ receptors in another cell line (10). In addition, adenosine-stimulated DNA synthesis was inhibited as follows in the presence of specific $\mathrm{A}_{1}$ - or $\mathrm{A}_{2 \mathrm{a}}$-adenosine receptor antagonists: $50 \%$ by $10 \mathrm{nM}$ or $25 \mathrm{nM}$ CPX; $60-70 \%$ by $1 \mathrm{nM} \mathrm{CSC}$. The data suggest that both $\mathrm{A}_{1}$ - and $\mathrm{A}_{2 \mathrm{a}}$-adenosine receptors are involved in the stimulation of DNA synthesis. In contrast to results with $3 \mathrm{~T} 3$ cells (11), NECA was not able to replace adenosine as a mitogen.

\section{Evidence for an interaction between $A_{1}$ - and $A_{2 a}$-adenosine receptors during adenosine- stimulated CAMP accumulation}

Elevation of cellular cAMP levels induced by adenosine was inhibited by either the $\mathrm{A}_{1^{-}}$ receptor antagonist, CPX, or the $\mathrm{A}_{2 \mathrm{a}}$-receptor antagonist, CSC (Fig. 5). This indicates that the $\mathrm{A}_{1}$ and $\mathrm{A}_{2 \mathrm{a}}$ receptors interacted in some way during adenosine-stimulated cAMP accumulation. Additional evidence for interaction (see Fig. 2) is the fact that prolonged preincubation with CPA or R-PIA, specific $\mathrm{A}_{1}$-adenosine agonists, caused partial inhibition of adenosine-dependent elevation in cAMP levels, while $\underline{\mathrm{APEC}}$, an $\mathrm{A}_{2 \mathrm{a}}$-adenosine agonist, had the same effect. The possible nature of this interaction is discussed below.

\section{DISCUSSION}

We have demonstrated the presence of $\mathrm{A}_{1}$ - as well as $\mathrm{A}_{2 \mathrm{a}}$-adenosine receptors in human diploid foreskin fibroblasts and in human diploid lung fibroblasts. The evidence is based mainly on pharmacological experiments with specific $\mathrm{A}_{1}$ and $\mathrm{A}_{2 \mathrm{a}}$ agonists and antagonists. In addition, binding of a radioactively labeled $\mathrm{A}_{1}$-receptor agonist to FS4 and HFF was measured.

In this paper, we have also presented evidence for an interaction between the $A_{1^{-}}$and $A_{2 a^{-}}$ adenosine receptors during adenosine-stimulated cAMP accumulation. The results can best be explained by a model proposed by Tang and Gilman (14). According to this model, $\mathrm{G}_{\mathrm{sa}}$ (activated when adenosine binds to $\mathrm{A}_{2 \mathrm{a}}$ receptors) interacts with $(\beta \gamma$ (released in high concentration when adenosine binds to $A_{1}$ receptors). The interaction causes enhanced stimulation of adenylyl cyclase II (or IV), greater than achieved by $\mathrm{G}_{\mathrm{sa}}$ alone. As explained in reference (15), agonists acting through "inhibitory" $\left(A_{1}\right)$ receptors coupled to $G_{i}$ are converted into stimulators of cAMP synthesis. The fact that cAMP accumulation by $\mathrm{G}_{\mathrm{sa}}$ is greatly potentiated by forskolin (16) is consistent with the presence of adenylyl cyclase II, and this is shown in Fig. 4. This type of interaction between $G_{s a}$ and $\beta \gamma$ was first observed by Tang and Gilman (14) and shown to occur in transfected intact cells in Bourne's laboratory (15).

As shown in Fig. 6, prior incubation with pertussis toxin caused substantial elevation in cAMP accumulation stimulated by APEC in FS4 cells. We interpret this result to mean that pertussis toxin ADP ribosylates $\mathrm{G}_{\mathrm{i}}\left(\right.$ and/or $\left.\mathrm{G}_{0}\right)$, with decrease in the affinity of the a subunit for the $\beta \gamma$ complex, as demonstrated by Casey et al. (12) and by Katoda et al. (13). The $\beta \gamma$ complex interacts with $\mathrm{G}_{\mathrm{sa}}$, activated by adenosine or APEC bound to $A_{2 \mathrm{a}}$ receptors, to cause enhanced accumulation of cAMP, greater than seen in the absence of pretreatment with pertussis toxin. The experiment shown in Fig. 6 has been repeated many times with all three cell types and with NECA, APEC, adenosine, or ATP as a source of $\mathrm{G}_{\mathrm{sa}}$. 
Enhanced accumulation of cAMP by interaction of $\mathrm{G}_{\mathrm{sa}}$ with $\beta \gamma$ was also seen in ongoing experiments in which human cells were incubated with the specific $\mathrm{A}_{2 \mathrm{a}}$-receptor agonist, APEC, together with the $\mathrm{A}_{1}$-adenosine receptor agonist, R-PIA. Even greater enhancement was seen with the combination of NECA and R-PIA (or CPA). Finally, we postulate that stimulation of cAMP accumulation by adenosine itself was the sum of a cAMP elevation due to activation of $\mathrm{G}_{\mathrm{sa}}$ after $\mathrm{A}_{2 \mathrm{a}}$-receptor binding, plus an augmentation caused by $\mathrm{G}_{\mathrm{S}}$ interacting with $\beta \gamma$ (released by activated $G_{i}$ ). This accounts for the inhibition produced either by an $\mathrm{A}_{1}$ antagonist or an $\mathrm{A}_{2 \mathrm{a}}$ antagonist (Fig. 5). A similar explanation accounts for the partial inhibition of adenosine-dependent cAMP accumulation in FS4 cells after desensitization of $\mathrm{A}_{1}$ receptors with prolonged exposure to R-PIA or CPA (Fig. 2). The augmentation due to interaction of $G_{s a}$ with $\beta \gamma$ is presumed to be lost by the desensitization. We ignore possible effects of $G_{i a}$, reported to be weak.

Current experiments involve transfection with the a subunit of transducin (15), or experiments using a fusion protein which is a specific probe that acts as a scavenger for $\beta \gamma$ subunits (17). These experiments can provide direct evidence for participation of $\beta \gamma$ in adenosine-dependent stimulation of cAMP accumulation.

\title{
Supplementary Material
}

Refer to Web version on PubMed Central for supplementary material.

\section{Acknowledgments}

This work was supported by grant 5 ROl CA58518 from the National Institutes of Health and by grants from the Cornell Center for Advanced Technology in Biotechnology (which is sponsored by the New York State Science and Technology Foundation, and by Johnson \& Johnson and industrial partners), and by USDA Hatch Project No. NYC-181412. We are grateful to Sharon Johnston for tissue culture assistance and to Ding-ji Wang who carried out some preliminary experiments. We thank Vicki Shaff for expert secretarial assistance.

\section{Abbreviations}

\author{
ADO adenosine \\ APEC 2-[(2-aminoethylamino)carbonyl-ethylphenyethylamino]-5' $-\mathrm{N}$ - \\ ethylcarboxamidoadenosine \\ CPA N-cyclopentyl-adenosine ( $\mathrm{A}_{1}$ agonist $)$ \\ CPX DPCPX, 8-cyclopentyl-1,3-dipropylxanthine ( $\mathrm{A}_{1}$ antagonist) \\ CSC 8-(3-chlorostyryl)caffeine ( $\mathrm{A}_{2 \mathrm{a}}$ antagonist) \\ FSK forskolin \\ LPA lysophosphatidic acid \\ NECA N-ethylcarboxamidoadenosine ( $\mathrm{A}_{2}$ agonist) \\ PTX pertussis toxin \\ RO20-1724 inhibitor of cAMP phosphodiesterase
}


R-PIA R-phenylisopropyladenosine ( $\mathrm{A}_{1}$ agonist). The adenosine analogues are described in great detail by Jacobson et al. (Drug Development Research 28, 226-231, 1993)

\section{References}

1. Stiles GL. J Biol Chm. 1992; 267:6451-6454.

2. Von Calker D, Muller DM, Hamprecht B. J Neurochem. 1979; 33:999-1005. [PubMed: 228008]

3. Ramkumar V, Barrington WW, Jacobson KA, Stiles GL. Mol Pharmacol. 1990; 37:149-156. [PubMed: 2304450]

4. Bronzon B, Nilsson J, Fredholm BB. J Cell Physiol. 1985; 124:451-456. [PubMed: 2995420]

5. Vilcek J, Havell EA. Proc Natl Acad Sci USA. 1973; 70:3909-3913. [PubMed: 4544057]

6. Huang N, Wang D, Heppel LA. J Biol Chem. 1993; 268:10789-10795. [PubMed: 8388375]

7. Wang D, Huang N, Heller EJ, Heppel LA. J Biol Chem. 1994; 269:16648-16655. [PubMed: 8206984]

8. Bruns RF, Fergus JH, Badger EW, Bristol JA, Santay LA, Hartman JD, Hays SJ, Huang CC. Naunyn Schmiedeberg's Arch Pharmacol. 1987; 335:59-63. [PubMed: 3574492]

9. Kartha S, Toback FG. Am J Physiol. 1985; 249:F967-F972. [PubMed: 4073277]

10. Ramkumar V, Olah ME, Jacobson KA, Stiles GA. Mol Pharmacol. 1991; 40:639-647. [PubMed: 1944235]

11. Rozengurt E. Exp Cell Res. 1982; 139:71-78. [PubMed: 6282602]

12. Casey PJ, Graziano MP, Gilman AG. Biochemistry. 1989; 28:611-616. [PubMed: 2496748]

13. Katada T, Oinuma M, Ui M. J Biol Chem. 1986; 261:5215-5221. [PubMed: 3082880]

14. Tang WJ, Gilman AG. Science. 1991; 254:1500-1503. [PubMed: 1962211]

15. Federman AD, Conklin BR, Schrader KA, Reed RR, Bourne HR. Nature. 1992; 356:159-161. [PubMed: 1312225]

16. Feinstein PG, Schrader KA, Bakalyar HA, Tang WJ, Krupinski J, Gilman AG, Reed RR. Proc Natl Acad Sci USA. 1991; 88:10173-10177. [PubMed: 1719547]

17. Inglese J, Luttrell LM, Tniguez-Lluhi JA, Touhara K, Koch WJ, Lefkowitz RJ. Proc Natl Acad Sci USA. 1994; 91:3637-3641. [PubMed: 8170960] 


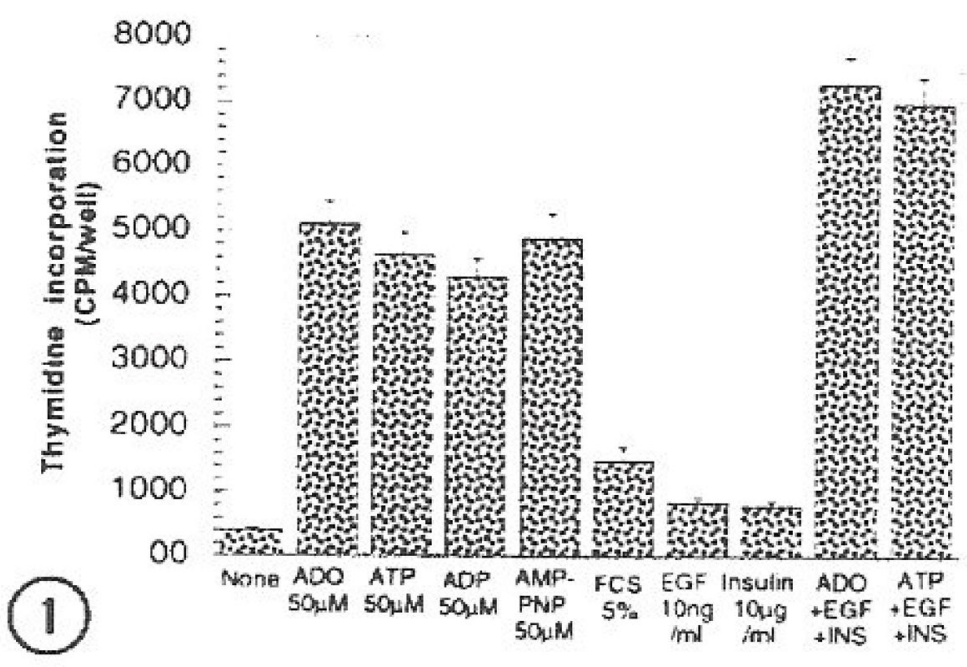

Fig. 1.

Stimulation of $\left[{ }^{3} \mathrm{H}\right]$ thymidine incorporation in quiescent FS4 cultures. Procedure as in "Methods". AMPPNP, adenosine 5'-[ $\beta \gamma$-imido]triphosphate; EGF, epidermal growth factor. 


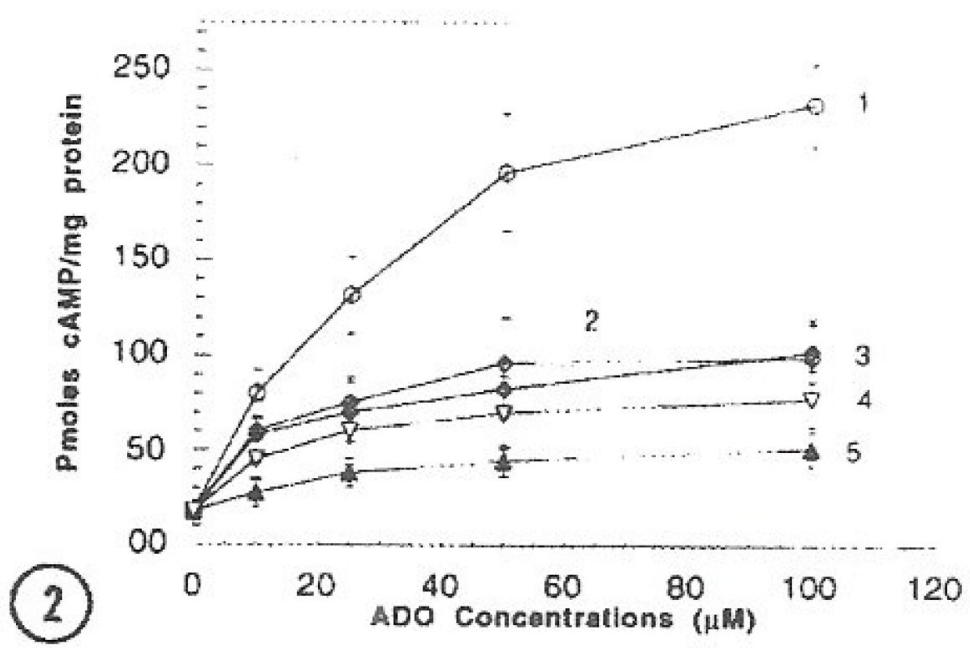

Fig. 2.

Concentration dependence for stimulation of cAMP accumulation by adenosine (Curve 1) and the effects of receptor desensitization. FS4 cells in 12-well clusters were washed and incubated at $37^{\circ} \mathrm{C}$ for 45 min with 1:1 DMEM:Waymouth medium containing adenosine as indicated. Cellular cAMP measured as in "Methods". Curve 1, control. Curves 2-5: Cells were pretreated for $24 \mathrm{~h}$ with $100 \mathrm{nM}$ R-PIA (Curve 2); $100 \mathrm{nM}$ CPA (Curve 3); $50 \mathrm{nM}$ APEC (Curve 4); $25 \mu \mathrm{M}$ ADO (Curve 5). After washing, adenosine was added as in Curve 1. 


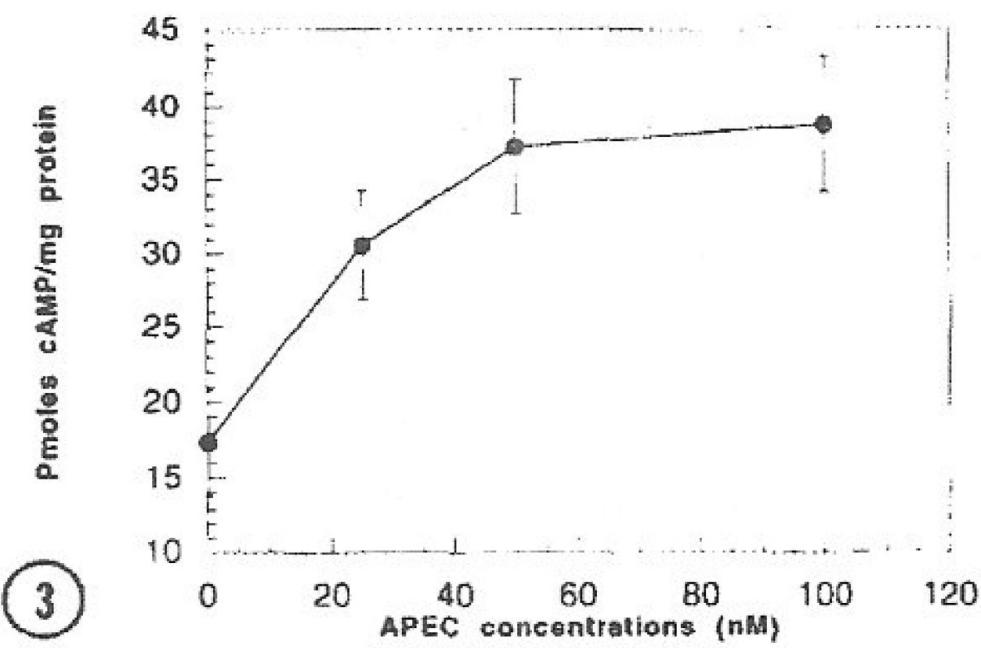

Fig. 3.

Concentration dependence for stimulation of cAMP levels by the $\mathrm{A}_{2 \mathrm{a}}$-adenosine receptor agonist, APEC, in FS4 cells. Conditions as in legend to Fig. 2. 


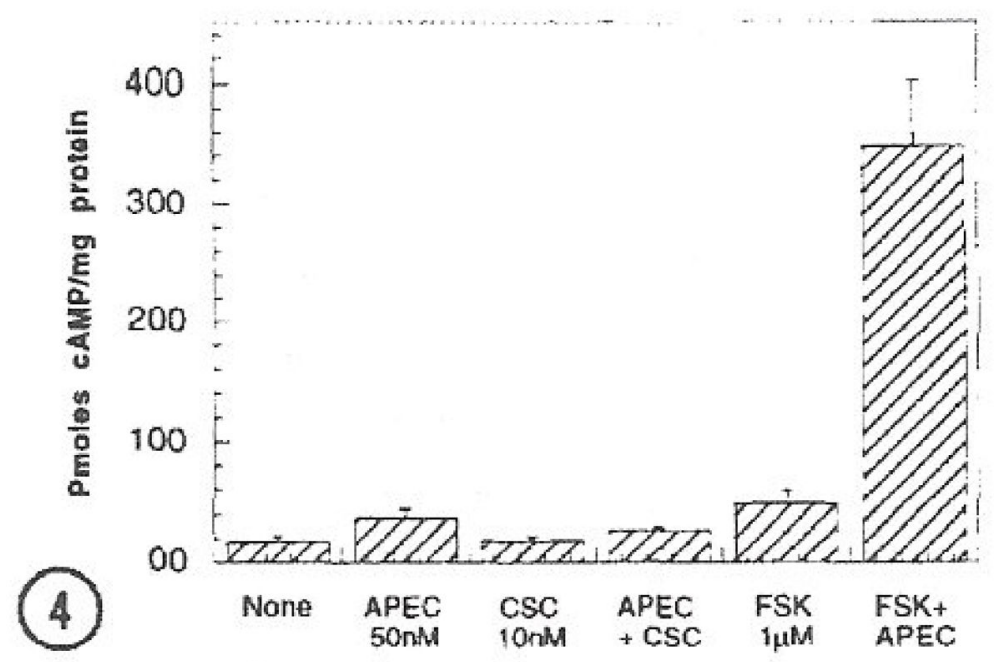

Fig. 4.

Effect of $10 \mathrm{nM} \mathrm{CSC}$, an $\mathrm{A}_{2 \mathrm{a}}$-adenosine receptor antagonist, on cAMP accumulation stimulated by $100 \mathrm{nM}$ APEC, an $\mathrm{A}_{2 \mathrm{a}}$ agonist. Conditions as in Fig. 2. Forskolin $(1 \mu \mathrm{M})$ caused a huge synergistic augmentation of the effect of $100 \mathrm{nM}$ APEC on cAMP levels, suggesting that FS4 cells contain adenylyl cyclases II or IV (16). 


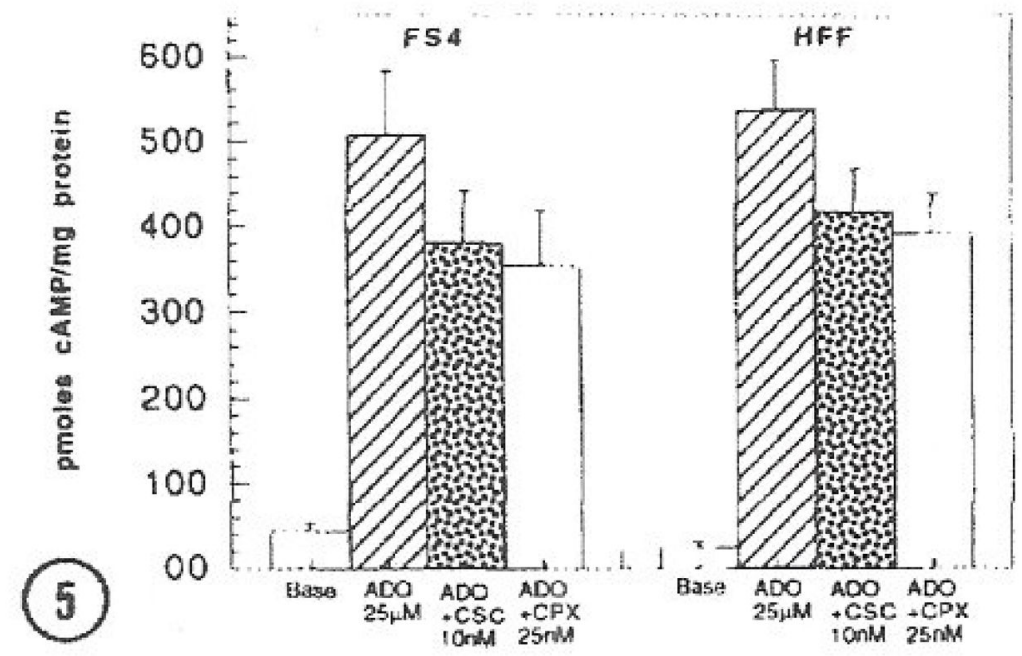

Fig. 5.

Effect of $25 \mathrm{nM}$ CPX and $10 \mathrm{nM} \mathrm{CSC}$, an $\mathrm{A}_{1}$ - and $\mathrm{A}_{2 \mathrm{a}^{-}}$-adenosine receptor antagonist, respectively, on cAMP accumulation stimulated by $25 \mu \mathrm{M}$ adenosine. Conditions as for Fig. 2 . 


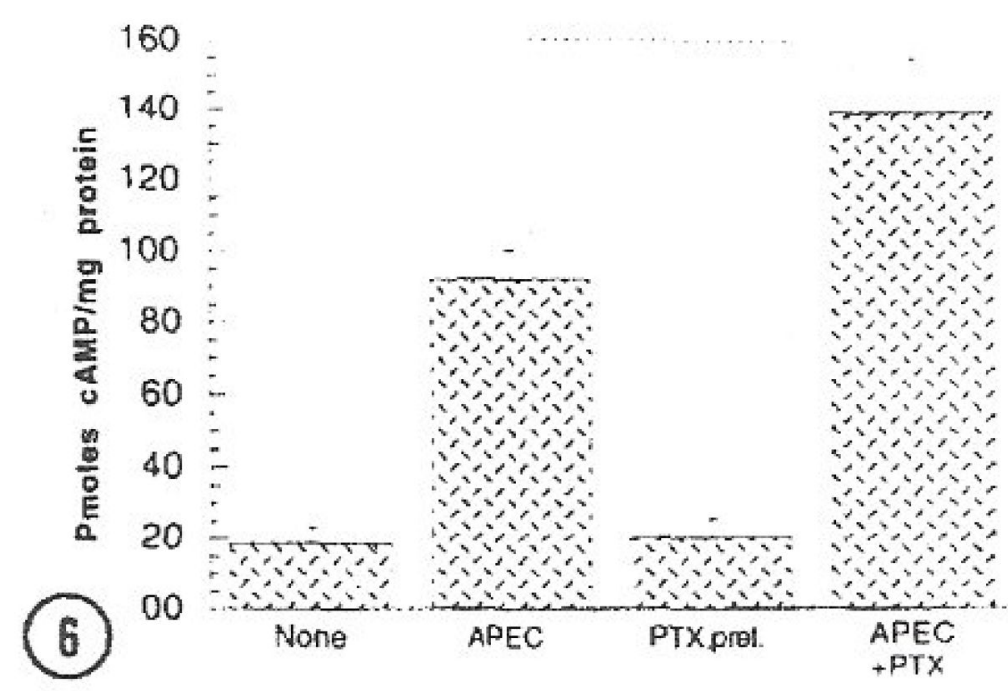

Fig. 6.

Effect of pretreatment with pertussis toxin (PTX) on the stimulation of cAMP accumulation by APEC, an $\mathrm{A}_{2 \mathrm{a}}$-adenosine receptor agonist. FS4 cells were incubated for $4 \mathrm{~h}$ in 1:DMEM:Waymouth medium with $50 \mathrm{ng} / \mathrm{ml}$ PTX. After washing, the cells, along with untreated controls, were assayed as usual for cAMP accumulation, using $100 \mathrm{nM}$ APEC to stimulate them. 


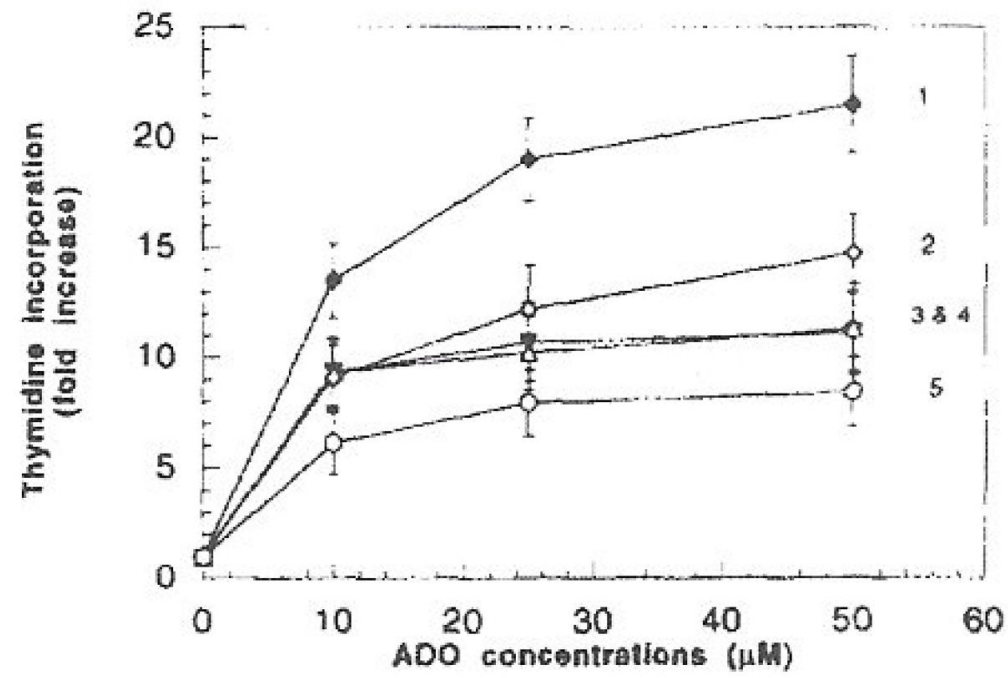

Fig. 7.

Partial inhibition of adenosine-stimulated $\left[{ }^{3} \mathrm{H}\right]$ thymidine incorporation after desensitization by $\mathrm{A}_{1}$ and $\mathrm{A}_{2 \mathrm{a}}$ receptor agonists, and greater desensitization by ADO. FS4 cells were preincubated for $24 \mathrm{~h}$ at $37^{\circ} \mathrm{C}$ with $100 \mathrm{nM}$ R-PIA or CPA (Curves 3 and 4), or $50 \mathrm{nM}$ APEC (Curve 2), or $25 \mu \mathrm{M}$ adenosine (Curve 5), and the control (Curve 1). The cells were washed and $\left[{ }^{3} \mathrm{H}\right]$ thymidine incorporation was measured in the presence of different levels of adenosine (see "Methods"). 